\title{
Lone mothers in Sweden: trends in health and socioeconomic circumstances, 1979-1995
}

\author{
Bo Burström, Finn Diderichsen, Susanna Shouls, Margaret Whitehead
}

\begin{abstract}
Study objective-To study trends in the health and socioconomic circumstances of lone mothers in Sweden over the years 1979-1995, and to make comparisons with couple mothers over the same period.

Design-Analysis of data from the annual Survey of Living Conditions (ULF), conducted by Statistics Sweden from 19791995. Comparison of demographic, socioeconomic and health status of lone and couple mothers and how these have varied over the 17 years of the study. Main outcome measures include prevalence of self perceived general health and limiting longstanding illness.
\end{abstract}

Participants and setting-All lone mothers $(n=2776)$ and couple mothers $(n=16935)$ aged 16 to 64 years in a random sample of the Swedish population in a series of cross sectional surveys carried out each year between 1979 and 1995 .

Main results-The socioeconomic conditions of lone mothers deteriorated during the period 1979-1995, with increasing unemployment and poverty rates. Lone mothers had worse health status than couple mothers throughout the period. In comparison with the first two periods, the prevalence of less than good health increased among both lone and couple mothers from the late 1980 s onwards. For lone and couple mothers who were poor, their rates of less than good health were similar in the early 1980s, but in 1992-95 poor lone mothers were significantly more likely to report less than good health than poor couple mothers. Unemployed lone mothers had particularly high rates of ill health throughout the study period.

Department of Public Health Sciences, Karolinska Institutet, Stockholm, Sweden B Burström

F Diderichsen

M Whitehead

Policy and Development Directorate, King's Fund, London S Shouls

M Whitehead

Correspondence to: Dr B Burström, Department of Public Health Sciences, Division of Social Medicine, Karolinska Institutet, SE-171

76 Stockholm, Sweden.

Accepted for publication

13 April 1999
In many countries lone mothers are considered a vulnerable group in society. ${ }^{1-4}$ Swedish social and labour market policies have long attempted to provide a supportive environment for all parents to be able to work, irrespective of marital status. In theory, lone mothers have had similar opportunities to earn their own living as other parents. In practice, this has been reflected in the high employment and low poverty rates among Swedish lone mothers, as compared with other countries. ${ }^{3-6}$

As the economic recession struck Sweden in the early 1990s, however, macroeconomic developments and retrenchment in the welfare state have occurred that may have had negative implications for the socioeconomic situation of Swedish lone mothers and for their health. ${ }^{7}$ Lone mothers were a focus of a recent report from the National Board of Welfare on the situation of vulnerable groups in Swedish society. ${ }^{8}$ Various groups were analysed in relation to having three or more problems concerning housing, work or earning a living. Of all lone mothers aged 25-64 years, $27 \%$ had three or more problems compared with $10 \%$ for the whole population. Lone mothers aged 25-34 years had a higher prevalence $(36 \%)$ of these problems, rising to $51 \%$ of those living in bigger cities.

Studies from Britain, ${ }^{9-12}$ North America, ${ }^{13} 14$ Finland ${ }^{15}$ and Norway ${ }^{16}$ have found poorer health status among lone mothers. Only a few studies have focused on the health of lone mothers in Sweden, ${ }^{17-19}$ and these too report a health disadvantage compared with couple mothers in the 1980s. One study found a similar level of self reported health among lone and couple mothers, but a higher prevalence of risk factors such as lack of social support and smoking among lone mothers. ${ }^{17}$ Another report summarising other studies pointed to the divide in living conditions and health between well educated and less educated lone mothers. The latter group was vulnerable in many respects, including financial vulnerability, poor working conditions and unemployment. ${ }^{18}$ Young lone mothers in Sweden have also been found to have a higher rate of suicide attempts than couple mothers. ${ }^{19}$ No study to our knowledge has studied the health of Swedish lone mothers over an extended period of time during which significant economic and social welfare changes have been taking place. The purpose of this paper is to present trends in self reported health among lone and couple mothers in Sweden during the period 1979-95, and to relate these to trends in their socioeconomic circumstances during the same time period. 
Table 1 Some characteristics of lone mothers in absolute terms (percentage of lone mothers) and in relative terms (odds ratio compared with couple mothers adjusted for age), Sweden, 1979-1995

\begin{tabular}{|c|c|c|c|c|c|c|c|c|}
\hline \multirow[b]{2}{*}{ Proportion of lone mothers } & \multicolumn{2}{|l|}{$1979-83$} & \multicolumn{2}{|l|}{$1984-87$} & \multicolumn{2}{|l|}{$1988-91$} & \multicolumn{2}{|l|}{$1992-95$} \\
\hline & $\begin{array}{l}\text { Prevalence } \\
\text { rate in } \%\end{array}$ & $\begin{array}{l}\text { Odds ratio } \\
\text { compared with } \\
\text { couple mothers }\end{array}$ & $\begin{array}{l}\text { Prevalence } \\
\text { rate in \% }\end{array}$ & $\begin{array}{l}\text { Odds ratio } \\
\text { compared with } \\
\text { couple mothers }\end{array}$ & $\begin{array}{l}\text { Prevalence } \\
\text { rate in } \%\end{array}$ & $\begin{array}{l}\text { Odds ratio } \\
\text { compared with } \\
\text { couple mothers }\end{array}$ & $\begin{array}{l}\text { Prevalence } \\
\text { rate in \% }\end{array}$ & $\begin{array}{l}\text { Odds ratio } \\
\text { compared with } \\
\text { couple mothers }\end{array}$ \\
\hline 1 In the total population & 3.0 & - & 2.9 & - & 2.9 & - & 3.3 & - \\
\hline 2 Of all mothers & 13.9 & & 13.4 & & 13.4 & & 16.0 & \\
\hline 3 Non-Swedish born & 15.6 & $1.6(1.3,1.9)$ & 15.4 & $1.3(1.0,1.7)$ & 17.5 & $1.8(1.4,2.3)$ & 20.5 & $1.6(1.3,2.0)$ \\
\hline 4 Employed full/part-time & 83.5 & $1.3(1.1,1.6)$ & 85.4 & $0.9(0.7,1.2)$ & 84.4 & $0.5(0.4,0.6)$ & 72.4 & $0.6(0.5,0.7)$ \\
\hline 5 Unemployed & 4.8 & $2.4(1.7,3.3)$ & 5.0 & $2.2(1.4,3.4)$ & 4.0 & $2.0(1.2,3.4)$ & 11.9 & $1.9(1.4,2.6)$ \\
\hline 6 With income $<50 \%$ of median income & $\mathrm{n} / \mathrm{a}$ & $\mathrm{n} / \mathrm{a}$ & 3.8 & $1.4(0.9,2.0)$ & 9.6 & $1.7(1.2,2.4)$ & 10.0 & $1.4(1.03,1.87)$ \\
\hline 7 With no post-primary education & 16.6 & $1.0(0.8,1.2)$ & 14.5 & $1.1(0.9,1.4)$ & 8.1 & $0.9(0.7,1.3)$ & 5.9 & $2.1(1.4,3.0)$ \\
\hline 8 With children aged $0-6$ years & 31.0 & $0.4(0.3,0.5)$ & 33.9 & $0.5(0.4,0.6)$ & 32.8 & $0.4(0.3,0.5)$ & 40.5 & $0.5(0.4,0.6)$ \\
\hline 9 With manual occupation & 46.4 & $0.8(0.7,0.9)$ & 51.1 & $1.1(1.0,1.4)$ & 47.5 & $1.0(0.8,1.1)$ & 47.6 & $1.1(0.9,1.3)$ \\
\hline 10 Who have experienced financial crisis & & & & & & & & \\
\hline past year & 33.3 & $3.5(3.0,4.0)$ & 41.4 & $4.6(3.4,6.1)$ & 44.7 & $5.3(4.3,6.4)$ & 49.6 & $4.0(3.3,4.8)$ \\
\hline 11 With less than good health & 22.3 & $1.6(1.4,1.9)$ & 21.3 & $1.8(1.4,2.2)$ & 26.4 & $2.1(1.7,2.6)$ & 27.8 & $1.8(1.5,2.2)$ \\
\hline 12 With limiting longstanding illness & 21.0 & $1.5(1.3,1.8)$ & 20.3 & $1.5(1.2,1.9)$ & 22.8 & $1.6(1.3,2.0)$ & 23.4 & $1.6(1.3,2.0)$ \\
\hline
\end{tabular}

$95 \%$ confidence intervals for odds ratios shown in parentheses.

\section{Methods}

SAMPLE

The study is based on secondary analysis of data from the Swedish Survey of Living Conditions (ULF) for the 17 years from 1979 to 1995 inclusive. The ULF has been carried out annually since 1975 by Statistics Sweden, using face to face interviews with a random sample, representative of the Swedish population aged 16 years and over. The dataset used in this study includes 89904 persons aged 16-64 years, of whom all 2776 lone mothers and 16935 couple mothers were studied. Data for the years 1979-95 have been pooled into four periods: $1979-83,1984-87,1988-91$ and 1992-95. The non-response rates in the surveys have been slowly increasing from $16.9 \%$ in 1979 to $19.5 \%$ in 1993 .

A lone mother is defined as a mother not currently living with a partner, but living with her children aged 18 years or less. As many children in Sweden regularly move between parents and live with either their father or their mother for periods of time, there is probably some misclassification. A couple mother is defined as a mother currently cohabiting with a partner and living with her children aged 18 years or less. Prevalence rates of health measures have been calculated by age groups. Age adjusted odds ratios (OR), with 95 per cent confidence intervals (CI), have been calculated with logistic regression using SAS (version 6.12). Analyses for trends over time were done using the $\chi^{2}$ test for linear trends. ${ }^{20}$

SOCIOECONOMIC AND HEALTH DATA

Data on income, only available from 1982 onwards, were supplied by Statistics Sweden from national tax registers, and were attached to the survey records of subjects using their personal identification number. By this method, almost complete income information was obtained for mothers in the sample, with no missing income values for lone mothers and very few for couple mothers. The measure of income used in this study was deflated and equivalised disposable family income, using the Statistics Sweden Equivalence Scale, which takes into account all income (wages and benefits) for all household members, net of taxes and adjusted for price inflation, family size and composition. The EU definition of poverty was used: income less than $50 \%$ of median income. In addition, responses to survey questions on the experience of "financial crisis" were analysed (see appendix 1).

Responses to survey questions on employment were coded into six categories: working full time (35 or more hours per week); working part time (less than 35 hours per week); looking after the home; early retired, unemployed; and economically inactive. Self reported health was assessed by answers to the questions listed in appendix 1.

\section{Results}

CHARACTERISTICS OF LONE MOTHERS AND

COUPLE MOTHERS

The age distribution was similar among lone and couple mothers throughout the study period, with only about $5 \%$ of both groups younger than 25 , and about $75 \%$ aged between 25 and 44 . The average age of both lone and couple mothers increased slightly over the period 1979-95.

Lone mothers made up approximately $3 \%$ of the total population throughout the study period, while the proportion of all mothers who were lone mothers increased significantly, from $13.4 \%$ in the early 1980 s to $16.0 \%$ in the 1990s. The proportion of mothers not born in Sweden also increased during the period among both lone and couple mothers, reaching $20 \%$ by $1992-95$ (table 1 ).

Employment rates among lone mothers were high in the first period, but declined from 1988-91. In the beginning of the period, lone mothers were more likely than couple mothers to be employed, but the case was reversed from the second half of the study period. The unemployment rate was low, at between $4 \%$ and 5\% throughout the 1980s, though higher for lone than couple mothers throughout the period and it increased for both groups in the 1990s. Poverty also increased for both lone and couple mothers over time. In 1982-87 there was no significant difference in prevalence of poverty between lone and couple mothers; however in 1988-91 and in 1992-95 lone mothers were significantly more likely to be poor than couple mothers. There was a steady increase in the proportion of lone mothers experiencing 


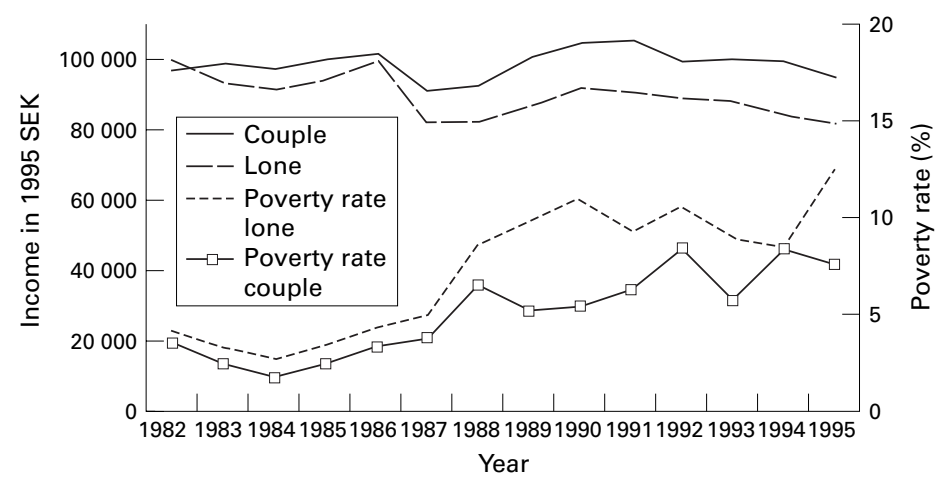

Figure 1 Trends in disposable income per consumption unit for lone and couple mothers 1982-1995, adjusted for inflation, in 1995 Swedish crowns (SEK), and trends in prevalence of poverty.
KEY POINTS

- Lone mothers have worse self rated health than couple mothers in Sweden.

- Employment rates have declined and poverty rates have increased among lone mothers from 1979 to 1995.

- In 1992-95 poor lone mothers reported significantly higher rates of less than good health than did poor couple mothers.

- Further research is needed to elucidate the reasons for lone mothers' health disadvantage as compared with couple mothers.

were looking after the home compared with $4.4 \%$ in $1992-95$.

The proportion economically inactive was higher in lone than in couple mothers throughout the period, and peaked in 1992-95 with $8.3 \%$ of lone mothers compared with $3.6 \%$ of couple mothers. The unemployment rate was about $2 \%$ for couple mothers right through the 1980 s, until 1992-95 when it had increased to $6.6 \%$. Rates of unemployment were higher among lone mothers throughout the period, and increased from $4.8 \%$ in $1979-83$ to $11.9 \%$ in 1992-95. Long term unemployment (longer than six months) increased in prevalence among both lone and couple mothers.

couple mothers to have no post-primary education.

Lone mothers were at a health disadvantage compared with couple mothers in all four time periods. Approximately a quarter of lone mothers reported less than good health (OR 1.6 to 2.1 compared with couple mothers). There was a linear trend of increase from $1979-83$ to $1992-95$ in the proportion of lone $\left(\chi^{2} 8.50, \mathrm{p}=0.004\right)$ and couple $\left(\chi^{2}\right.$ 6.85, $\mathrm{p}=0.009)$ mothers reporting less than good health. Rates of limiting longstanding illness were also between $50 \%$ and $60 \%$ higher than for couple mothers (table 1), but there was no significant linear trend of increase among lone $\left(\chi^{2} 1.74, \mathrm{p}=0.188\right)$ or couple $\left(\chi^{2} 1.31\right.$, $\mathrm{p}=0.253)$ mothers.

\section{EMPLOYMENT TRENDS}

Employment rates for lone and couple mothers ranged from 70-90\% between 1979 and 1995. In the beginning of the period lone mothers had higher employment rates $(83.5 \%)$ than couple mothers (79.3\%). During the middle of the 1980 s rates were over $85 \%$ for both groups. From the end of the 1980s this trend changed, and couple mothers had higher employment rates than did lone mothers from 1988-91 (89.4\% compared with $84.4 \%$ ). By $1992-95$ the rates had declined in both groups, to $82.4 \%$ in couple mothers and $72.4 \%$ of lone mothers. Among couple mothers there was a linear trend of increase in employment $\left(\chi^{2}\right.$ 52.4, $\mathrm{p}=0.000001)$, while lone mothers showed a decreasing linear trend of employment $\left(\chi^{2}\right.$ 24.8, $\mathrm{p}=0.000001)$. Among couple mothers the increase in employment rate was attributable to a decline in the proportion looking after the home, from $14.6 \%$ in $1979-83$ to $6.4 \%$ in 1992-95. In 1979-83 $3.1 \%$ of lone mothers

\section{TRENDS IN FINANCIAL SITUATION}

At the beginning of the period lone and couple mothers had very similar income levels (fig 1). From the second half of the 1980s, the deflated income of both groups declined, more so for lone mothers. From the end of the 1980s to 1995 a distinct difference in income appeared, to the disadvantage of lone mothers, whose median income in 1995 was about $85 \%$ of the median of couple mothers. Figure 1 also illustrates the growth in poverty among lone and couple mothers. There was a linear trend of increase in the rate of poverty among lone $\left(\chi^{2}\right.$ $78.2, \mathrm{p}=0.000001)$ and among couple mothers $\left(\chi^{2} 312.5, p=0.000001\right)$. Lone mothers were much more likely to experience financial crisis, and the gap between lone and couple mothers widened, particularly from $1984-87$ to 1988-91 (table 1).

TRENDS IN HEALTH AT DIFFERENT AGES

The prevalence of less than good health in the age group 16-44 years increased over time among both lone $\left(\chi^{2} 12.5, \mathrm{p}=0.0004\right)$ and couple mothers $\left(\chi^{2} 8.1, p=0.004\right)$. Disaggregating the data reveals higher prevalences of ill health in specific subgroups of mothers and an indication of a deterioration over time for some. Table 2 shows the age specific prevalence of less than good health was highest in lone mothers aged 45 years and above. However, the difference between lone and couple mothers was more than double among those aged 25-34 years. For the youngest group of lone mothers, aged 16-24, the prevalence of less than good health increased sharply from $24.2 \%$ in $1988-91$ to $40.5 \%$ in the period $1992-95$. Among couple and lone mothers aged 16-44 
Table 2 Age specific prevalence (\%) of less than good health and limiting longstanding illness for lone and couple mothers, Sweden, 1979-1995

\begin{tabular}{|c|c|c|c|c|c|c|c|c|}
\hline & \multicolumn{2}{|c|}{ Age 16-24 } & \multicolumn{2}{|c|}{ Age 25-34 } & \multicolumn{2}{|c|}{ Age 35-44 } & \multicolumn{2}{|c|}{ Age 45-64 } \\
\hline & lone & couple & lone & couple & lone & couple & lone & couple \\
\hline \multicolumn{9}{|l|}{ Less than good health } \\
\hline \multicolumn{9}{|l|}{ Period } \\
\hline $1979-83$ & 18.2 & 12.4 & 20.2 & 10.8 & 22.5 & 15.2 & 27.3 & 25.0 \\
\hline 1984-87 & 10.5 & 6.7 & 19.6 & 10.1 & 21.5 & 13.5 & 27.4 & 20.3 \\
\hline $1988-91$ & 24.2 & 14.5 & 24.8 & 10.9 & 25.5 & 14.8 & 30.7 & 21.1 \\
\hline 1992-95 & 40.5 & 18.5 & 26.6 & 15.2 & 25.9 & 16.6 & 30.0 & 22.1 \\
\hline Average 1979-1995 & 22.4 & 12.8 & 22.3 & 11.5 & 23.7 & 15.0 & 28.7 & 22.4 \\
\hline OR $(95 \% \mathrm{CI})$ & 1.98 & $(1.29,3.03)$ & 2.20 & $(1.84,2.64)$ & 1.76 & $(1.51,2.05)$ & 1.38 & $(1.12,1.70)$ \\
\hline \multicolumn{9}{|l|}{ Limiting longstanding illness } \\
\hline \multicolumn{9}{|l|}{ Period } \\
\hline $1979-83$ & 16.7 & 10.6 & 16.9 & 11.4 & 20.7 & 14.7 & 28.2 & 26.3 \\
\hline $1984-87$ & 23.7 & 8.5 & 16.2 & 10.9 & 22.0 & 14.1 & 22.1 & 24.1 \\
\hline 1988-91 & 6.1 & 13.9 & 18.6 & 12.6 & 24.9 & 15.5 & 28.8 & 21.6 \\
\hline 1992-95 & 27.8 & 15.4 & 17.1 & 13.2 & 23.0 & 15.0 & 33.8 & 22.2 \\
\hline Average 1979-1995 & 18.5 & 11.7 & 17.1 & 11.9 & 22.3 & 14.8 & 29.2 & 24.0 \\
\hline OR $(95 \% \mathrm{CI})$ & 1.72 & $(1.08,2.71)$ & 1.53 & $(1.26,1.86)$ & 1.65 & $(1.41,1.93)$ & 1.31 & $(1.06,1.61)$ \\
\hline Average number in each time period & 44 & 218 & 221 & 1512 & 290 & 1799 & 139 & 705 \\
\hline
\end{tabular}

$\mathrm{OR}=$ odds ratios for difference in prevalence of health measure between lone and couple mothers by age group: all years combined. $(95 \% \mathrm{CI})=95 \%$ confidence intervals.

years the absolute prevalence of less than good health increased, to varying degrees, from 1988-91 to $1992-95$ (table 2).

The odds ratios given in table 2 suggest that the health gap, in relative terms, between lone and couple mothers reduces somewhat with age. For self perceived general health, for example, the odds ratio reduces from 2.20 in the 25-34 year olds, to 1.38 for the oldest age group, a difference in odds ratios that is statistically significant. For limiting longstanding illness, the OR reduces from 1.72 for the youngest mothers to 1.31 for the oldest age group, though the difference between age groups did not reach statistical significance in this case.

HEALTH OF POOR AND NOT-POOR MOTHERS

Separate analyses were carried out for mothers living in and out of poverty. The prevalence rates of less than good health increased over time among poor lone mothers, while rates declined slightly among poor couple mothers; as a result the health gap widened between the two groups (table 3 ). However, these changes did not reflect a statistically significant trend in either case ( $\chi^{2}$ for linear trend was $0.38, p=0.54$ for couple mothers, and $\chi^{2}$ for linear trend was 3.36, $\mathrm{p}=0.067$ for lone mothers). Among lone and couple mothers who were not poor, there was a slight increase in prevalence of less than good health, but no change in the differential. In 1992-95 poor lone mothers were significantly more likely to report less than good health than poor couple mothers.
Prevalence rates of limiting longstanding illness in all age groups changed less over time than for self perceived general health (table 2). There was no significant difference between poor lone and poor couple mothers, and no significant changes over time. However, there were marked differences between mothers who were not poor for this health measure: lone mothers who were not poor had a significantly higher rate of limiting longstanding illness than not-poor couple mothers over the whole study period (table 3 ).

When comparisons were made between couple mothers living above and below the specified poverty level, poor couple mothers were found to have worse health than those who were not poor for both measures of ill health in all three time periods (table 3 ). That was not always the case for lone mothers living above and below the poverty level. As shown in table 3, rates of limiting longstanding illness were similar, or slightly lower, among poor lone mothers compared with those who were not poor.

HEALTH OF MOTHERS IN AND OUT OF WORK

Rates of less than good health were significantly higher among employed lone mothers than among employed couple mothers throughout the study period, and with prevalence among lone mothers increasing from the late 1980s onwards (table 4). Among the unemployed, the rate of less than good health was much higher for unemployed lone mothers

Table 3 Prevalence (\%) of less than good health and limiting longstanding illness among poor and non-poor lone and couple mothers, Sweden, 1982-1995: ages 16-64

\begin{tabular}{lllllll}
\hline Period & $\begin{array}{l}\text { Non-poor } \\
\text { couple }\end{array}$ & $\begin{array}{l}\text { Non-poor } \\
\text { lone }\end{array}$ & OR (95\% CI) & $\begin{array}{l}\text { Poor } \\
\text { couple }\end{array}$ & $\begin{array}{l}\text { Poor } \\
\text { lone }\end{array}$ & OR (95\% CI) \\
\hline $\begin{array}{l}\text { Less than good health } \\
\text { 1982-87 }\end{array}$ & 12.7 & 21.8 & $1.72(1.43,2.07)$ & 22.0 & 17.6 & $0.88(0.33,2.36)$ \\
$1988-91$ & 14.1 & 25.8 & $2.05(1.64,2.56)$ & 20.1 & 32.1 & $1.64(0.83,3.25)$ \\
1992-95 & 17.1 & 26.8 & $1.77(1.43,2.18)$ & 19.5 & 36.5 & $2.38(1.30,4.36)$ \\
Limiting longstanding illness & & & & & \\
1982-87 & 14.1 & 20.5 & $1.53(1.27,1.83)$ & 23.1 & 17.6 & $0.90(0.33,2.47)$ \\
1988-91 & 15.2 & 23.0 & $1.60(1.27,2.02)$ & 19.2 & 20.8 & $1.02(0.47,2.20)$ \\
1992-95 & 15.5 & 23.6 & $1.66(1.33,2.07)$ & 19.6 & 22.2 & $1.29(0.65,2.59)$ \\
Average number in each time period & 4045 & 644 & & 205 & 50 &
\end{tabular}

$\mathrm{OR}=$ age adjusted odds ratios (OR) for difference between lone and couple mothers in each time period and poverty category. $(95 \% \mathrm{CI})=95 \%$ confidence intervals. 
Table 4 Prevalence (\%) of less than good health and limiting longstanding illness among unemployed and employed lone and couple mothers, Sweden, 1979-1995: ages 16-64

\begin{tabular}{|c|c|c|c|c|c|c|}
\hline Period & $\begin{array}{l}\text { Employed } \\
\text { couple }\end{array}$ & $\begin{array}{l}\text { Employed } \\
\text { lone }\end{array}$ & OR $(95 \% C I)$ & $\begin{array}{l}\text { Unemployed } \\
\text { couple }\end{array}$ & $\begin{array}{l}\text { Unemployed } \\
\text { lone }\end{array}$ & OR $(95 \% C I)$ \\
\hline \multicolumn{7}{|l|}{ Less than good health } \\
\hline $1979-83$ & 14.9 & 21.5 & $1.51(1.24,1.82)$ & 14.7 & 38.7 & $3.56(1.67,7.58)$ \\
\hline 1984-87 & 13.1 & 20.6 & $1.76(1.38,2.26)$ & 15.5 & 34.5 & $4.21(1.45,12.26)$ \\
\hline $1988-91$ & 14.4 & 26.2 & $1.94(1.53,2.46)$ & 18.6 & 31.8 & $2.20(0.71,6.83)$ \\
\hline 1992-95 & 16.8 & 26.9 & $1.53(1.19,1.96)$ & 23.9 & 34.7 & $1.69(0.95,2.99)$ \\
\hline \multicolumn{7}{|l|}{ Limiting longstanding illness } \\
\hline $1979-83$ & 15.0 & 20.0 & $1.40(1.15,1.70)$ & 18.7 & 41.7 & $3.07(1.48,6.35)$ \\
\hline 1984-87 & 14.1 & 19.7 & $1.30(1.00,1.68)$ & 21.1 & 31.0 & $2.58(0.91,7.33)$ \\
\hline $1988-91$ & 15.2 & 22.6 & $1.48(1.15,1.90)$ & 29.0 & 27.3 & $0.94(0.32,2.81)$ \\
\hline $1992-95$ & 15.5 & 22.6 & $1.41(1.08,1.83)$ & 19.4 & 30.7 & $1.76(0.96,3.23)$ \\
\hline Average number in each time period & 4105 & 650 & & 128 & 44 & \\
\hline
\end{tabular}

$\mathrm{OR}=$ age adjusted odds ratios for difference between lone and couple mothers in each time period and employment category. $(95 \% \mathrm{CI})=95 \%$ confidence intervals.

than for couple mothers in the same situation. While the prevalence remained fairly constant for lone mothers ( $\chi^{2}$ for linear trend 0.20, $\mathrm{p}=0.66$ ), there was a statistically significant increase in trend of less than good health over time for unemployed couple mothers $\left(\chi^{2} 5.24\right.$, $\mathrm{p}=0.022)$, reducing the health differential between the two groups.

The prevalence of limiting longstanding illness among unemployed lone mothers also stood out as being high (table 4), particularly in 1979-83, when it was significantly different from unemployed couple mothers. In later years, the difference was not statistically significant. Among employed lone and couple mothers the prevalence of limiting longstanding illness was significantly higher among lone mothers throughout the period 1979-1995.

When employed and unemployed couple mothers were compared, there were small differences in less than good health in the1980s, which were not statistically significant, but significantly poorer health of unemployed couple mothers compared with their employed counterparts in 1992-95. Health differences between employed and unemployed couple mothers were more pronounced for limiting longstanding illness from 1984 to 1991. Unemployed lone mothers had some of the highest prevalence rates for both measures of ill health throughout the study period. Furthermore, these were substantially higher than the rates for employed lone mothers (table 4).

\section{Discussion}

METHODOLOGICAL CONSIDERATIONS

Although the sample size of couple $(n=16$ 935) and lone $(n=2776)$ mothers was considerable, the number of poor lone mothers in the period 1982-87 was quite small $(n=34)$. Hence estimates of health measures among the subgroup of poor mothers have wide confidence limits, and should be taken as suggestive only. The study is based on a series of cross sectional interview surveys, which limits the inference of causality. There is however little evidence in the literature to indicate that lone motherhood is to a major extent an effect of ill health. The health measures used were self reported and hence more subject to bias than measures of more medically or socially defined ill health. However, studies that have related self perceived general health to subsequent clinical measures of health have found that the measure has a strong predictive power for morbidity and mortality. ${ }^{21}$ More important would be if the misclassification were differential over time or in terms of the relevant exposures, but we have little reason to believe that. Data on income levels were obtained from national tax registers, probably the most appropriate and complete source available. However, even in this register the income of self employed persons and students may not fully reflect their economic standard of living.

\section{DETERIORATING SOCIOECONOMIC}

CIRCUMSTANCES

The socioeconomic circumstances of both lone and couple mothers, indicated by employment and poverty trends, deteriorated over the study period, especially from the late 1980 s onwards. These results are in line with other observations of an increase in receipt of social assistance among lone mothers. While $25 \%$ of lone mother households received social assistance in 1970, the proportion rose to $43 \%$ in 1985 and $38 \%$ in $1990 .{ }^{22}$ In 1991, 1993 and 1995 the average proportion of lone mothers receiving social assistance was $35 \%$, compared with $4-6 \%$ of couple mothers. ${ }^{8}$ Decreasing workforce participation rates and increasing unemployment rates resulted in increasing reliance on state transfers and on social welfare assistance. ${ }^{23}$ In addition, the economic recession during the early 1990s resulted in frozen or reduced levels of state benefits and a stricter policy towards social welfare assistance. The combined effect of these two trends is likely to be one explanation for the observed increase in rates of poverty among lone mothers.

\section{HEALTH OF LONE MOTHERS}

Lone mothers in Sweden had worse health than couple mothers, for all health outcome measures and in all four periods in this study. These overall inequalities in health between lone and couple mothers changed only slightly over time from 1979 to 1995, and were similar in magnitude to those reported for Britain in the 1990s. ${ }^{9}$ However, the health trends differed for specific sub-groups of women in the population. Younger women (aged 16-44) experienced an increase in prevalence rates of less than good health in the last two periods, both for lone and couple mothers. Furthermore, the association of less than good health and being a lone mother seemed most pronounced in 
younger than in older age groups, and the increase started earlier among lone mothers than among couple mothers. In contrast, the rate of limiting longstanding illness did not change over time. The increase in the prevalence of less than good health coincided with changes in social policies and more difficult times on the labour market. Restrictive changes in welfare state support for parents and increased competition on the labour market may increase the strain on mothers of young children, for a number of reasons. Young mothers have younger and more demanding children; roles of parenting and working conflict to a greater degree in these ages; financial problems are also more common in younger than in older ages, especially among lone mothers. ${ }^{24}$

\section{POOR AND UNEMPLOYED SUBGROUPS}

Other specific subgroups that may be particularly vulnerable to the deteriorating economic climate include poor or unemployed women. In this study, the prevalence of poverty was found to be higher in lone than in couple mothers and increased with time in both groups. Nevertheless, in international comparisons poverty rates among Swedish lone mothers were still low, even in the $1990 \mathrm{~s}^{23}$ The prevalence of less than good health increased among poor lone mothers, at the same time as the rates decreased among poor couple mothers, widening the gap between the two. This raises the question of whether there were factors buffering the effect of poverty among poor couple mothers that were not available to poor lone mothers. There was also a substantial health gap between lone and couple mothers who were not poor, but this did not widen over time. The high rates of less than good health among unemployed lone mothers and increasing rates among unemployed couple mothers are notable and also require further investigation.

In conclusion, we can only speculate as to the causes of the increased rates of less than good health among all mothers aged 16-44 years from 1988 and onwards. Despite the differential increase in prevalence of unemployment and poverty over the period 1982-1995, the health differential between lone and couple mothers remained fairly constant. Stable inequalities in health do not necessarily mean that the health of lone mothers has not been affected by deteriorating socioeconomic conditions. There are indications from this study that the health of poor lone mothers in particular seems to have deteriorated and should be the focus of further studies. The increasing rates of less than good health in lone and couple mothers aged 16-44 years from 1988-91 to 1992-95 may reflect a perception of more adverse socioeconomic conditions, and their negative influence on self perceived health. Therefore, in relative terms the inequalities are unchanged, but the higher prevalence levels of less than good health suggest deteriorating absolute levels of self perceived general health in both lone and couple mothers.
Improving educational levels is commonly advocated as an important strategy to tackle inequalities. In Sweden, although the overall proportion of lone mothers with no postprimary education has decreased, in 1992-95 lone mothers were at higher odds of having low education compared with couple mothers. The present development of decreasing workforce participation levels, decreasing disposable income and increasing poverty levels among lone mothers would seem to defeat the aim of Swedish policies concerning lone mothers, which is for them to be self supporting through work participation. According to our data, in the beginning of the 1980s lone mothers were able to support themselves and their children to a greater degree than in the 1990s.

At least two different mechanisms may operate in mediating the poorer health found in lone mothers compared with couple mothers: one is concerned with economic, social and cultural factors that lone mothers may be more exposed to; the other is concerned with the fact that lone mothers may be more susceptible to specific exposures such as poverty or unemployment.

Conflicts of interest: none. Funding: S Shouls and $M$ Whitehead are funded by the British
Economic and Social Research Council as part of the Health Variations Research Programme, grant number L128251029. B Burström and F Diderichsen are funded by grants from the Stockholm County Council and the National Institute of Public Health.

\section{Appendix 1}

\section{ULF Survey questions}

\section{Financial crisis}

1 Has there been any occasion during the last 12 months when you have found it difficult to meet the current expenses for food, rent, bills, etc?

2 Has there been any occasion during the last 12 months when there has been no money left and you have had to borrow from friends and relatives or ask for social assistance? An affirmative answer to both of these questions defined those having experienced "financial crisis".

\section{Self perceived general health}

How do you consider your general health condition? "Good", "bad", or "something in between". The answers "bad" or "something in between" are referred to as "less than good health" and taken as an indicator of self perceived poor general health.

\section{Limiting longstanding illness}

Do you suffer from any long term illness, after effects from an accident, disability or other ailment, yes or no? If yes, is your capacity to work or your ability to move about reduced as a consequence of your illness? Respondents who answered in the affirmative to both were classed as having a limiting longstanding illness.

1 Council of Europe Committee of Experts on the Health Problems of Single Parent Families. Health aspects of singleparent families: report on the psychosocial aspects of singleparent families and recommendation no. $R$ (97) 4 on securing and promoting the health of single-parent families. Strasbourg: Council of Europe Publishing, 1997.

2 Ford R, Millar J, eds. Private lives and public responses: lone parenthood and future policy in the UK. London: Policy Studies Institute, 1998.

3 Hobson B. Solo mothers, social policy regimes, and the logics of gender. In: Salisbury D, ed. Gendered welfare states. London: Sage, 1995:170-87. 
4 Wong Y-L, Garfinkel I, McLanahan S. Single-mother families in eight countries: economic status and social policy. Social Service Review 1993;67:177-97.

5 Sorensen A. Women's economic risk and the economic position of single mothers. European Sociological Review 1994;10:173-88

6 Hobson B, Takahashi M. The parent-worker model: lone mothers in Sweden. In: Lewis J, ed. Lone mothers in European welfare regimes. London: Jessica Kingsley, 1997: 121-39. 7 Ensamföräldrarna - en utsatt grupp? (Lone parents - a partementet, 1996. [In Swedish]

8 Social Rapport 1997. (Social report 1997, National Board of Welfare). Stockholm: Socialstyrelsen, 1997. [In Swedish].

9 Benzeval M. The self-reported health status of lone parents. Soc Sci Med 1998;46:1337-53.

10 Popay J, Jones G. Patterns of health and illness amongst lone parents. Fournal of Social Policy 1990;19:499-534.

11 Blaxter M. Health and lifestyles. London: Tavistock/ Routledge, 1990.

12 Macran S, Clarke L, Joshi H. Women's health: dimensions and differentials. Soc Sci Med 1996;42:1203-16.

13 Kotler P, Wingard D. The effect of occupational, marital and parental roles on mortality: the Alameda County Study. Am f Public Health 1989;79:607-12.

14 Walters V. Stress, anxiety and depression: women's accounts of their health problems. Soc Sci Med 1993;36:393-402.
15 Martikainen P. Women's employment, marriage, motherhood and mortality: a test of the multiple role and role accumulation hypotheses. Soc Sci Med 1995;40:199-212.

16 Elstad J. Inequalities in health related to women's marital, parental, and employment status - a comparison between
the early 70 s and the late 80 s, Norway. Soc Sci Med 1996; 42:75-89.

7 Forssén A, Janlert U. Ensamstående mödrar har ökad risk för ohälsa. (Lone mothers are at increased risk of ill health). Allmänmedicin 1991;12:71-6. [In Swedish]

18 Wasserman D. Flest självmordsförsök bland unga, frånskilda mödrar. (Most suicide attempts among young, divorced mothers) Social Forskning 1990;4:6-7. [In Swedish]

19 Ensamma mammor. En rapport om ensamstående mödrars hälsa och livsvillkor. (Lone mothers. A report on the health and living conditions of lone mothers). Stockholm: Folkhälsoinstitutet, 1994. [In Swedish].

20 Rothman KJ, Greenland S. Modern epidemiology. 2nd ed. Philadelphia: Lippincott-Raven, 1998.

21 Idler EL, Benyamini Y. Self-rated health and mortality: a review of twenty-seven community studies. F Health Soc review of twenty-seven
Behav 1997;38:21-37.

22 Salonen T. Margins of welfare. Torna Hällestad: Hällestad Press, 1993.

23 Duncan S, Edwards R, eds. Single mothers in an international context: mothers or workers? London: UCL Press, 1997.

24 Piachaud D. Round about fifty hours a week. London: Child Poverty Action Group, 1984. 